ISSN 0258-7122 (Print), 2408-8293 (Online)

Bangladesh J. Agril. Res. 44(3): 537-552, September 2019

\title{
PERFORMANCE OF LENTIL-MUNGBEAN-T.AUS RICE-T.AMAN RICE AGAINST EXISTING CROPPING PATTERN LENTIL-JUTE- T.AMAN RICE IN FARIDPUR REGION
}

\author{
S. AHMED ${ }^{1}$, A. F. M. R. QUDDUS ${ }^{2}$, M. MOHIUDDIN ${ }^{3}$ \\ M. R. ISLAM ${ }^{4}$ AND M. A. HOSSAIN ${ }^{5}$
}

\begin{abstract}
A trial was conducted in the farmers' field at Farming Systems Research and Development (FSRD) site, Hatgobindapur, Faridpur during 2014-15 and 201516 to develop an alternate cropping pattern over existing cropping pattern for increasing cropping intensity, total productivity as well as farmers' income. The alternate cropping pattern Lentil (var. BARI Masur-7)- Mungbean (var. BARI Mung- 6)- T. Aus rice (var. BRRI dhan48)- T.Aman rice (var. BRRI dhan62) was tested against the existing cropping pattern Lentil (var. Local)Jute (var. JRO 524)- T.Aman rice (var. BRRI dhan33). All the four crops in the AP were grown successfully within stipulated time frame following recommended practices. Crop duration and turn around time in alternate cropping pattern were 340 days and 25 days while that in existing cropping pattern were 313 days and 52 days, respectively. Cropping intensity increased from $300 \%$ (in existing pattern) to $400 \%$ in the alternate cropping pattern. Two years results showed that, average yield of T.Aus rice, T.Aman rice, Lentil and Mungbean in the alternate cropping pattern were 3.75, 4.17, 1.31 and $0.80 \mathrm{t} \mathrm{ha}^{-1}$, respectively. The rice equivalent yield and production efficiency was increased by 18 and 35\%, respectively over existing pattern. The gross margin of the whole alternate cropping pattern was Tk.106304 ha ${ }^{-1}$ whereas Tk. $75480 \mathrm{ha}^{-1}$ from existing cropping pattern. The alternate pattern provided $41 \%$ higher gross margin over existing cropping pattern. The MBCR was 4.86 over existing cropping pattern.
\end{abstract}

Keywords: Four crops based pattern, cropping intensity, production efficiency, rice equivalent yield, MBCR

\section{Introduction}

Agriculture in Bangladesh is the largest economic sector that provides more than $16 \%$ of the country's GDP and employs $45 \%$ of labour forces (BBS 2016). Bangladesh is one of the most densely populated countries of the world with population growth rate of $1.34 \%$ (BBS, 2017). Food requirement is estimated to be doubled in the next 25 years. With increase in population agricultural land is decreasing at an alarming rate for construction of housing, roads and other

${ }^{1}$ Senior Scientific Officer, ${ }^{2}$ Scientific Officer, ${ }^{3}$ Principal Scientific Officer, On-Farm Research Division (OFRD), BARI, Faridpur; ${ }^{4}$ Chief Scientific Officer and ${ }^{5}$ Senior Scientific Officer, On-Farm Research Division, BARI, Gazipur. 
infrastructures. Thus major challenge is to produce more and more food to feed the ever increasing populations from limiting land area. In this situation, increasing cropping intensity is indispensable and as such more crop(s) should be accommodated in the existing two or three crops based cropping patterns. Sustain crop production in Bangladesh through improvement of cropping pattern in the rice based cropping system is regarded important to address national issues such as, food security, poverty alleviation, land degradation and pollution control (Aziz and Rahman, 2011). The main challenge of the new millennium is increase yield per area unit by at least 50\% through manipulating the limited land resource. In this regard, the challenges for the agronomist are to understand crop production problems and process to develop the best ways of production technologies for the management of problems and sustain production. In case of production agronomy, targeting high yield with highest cropping intensity and productivity are the most logical way to raise the total production. In order to produce more food within a limited area, two most important options to be adopted are i) to increase the cropping intensity producing three or more crops in the same piece of land round the year and ii) to increase the production efficiency of the individual crop. Lentil-Jute-T.Aman rice covers 5\% of total cultivable land in Faridpur. Jute is one of the major cash crops in Faridpur region which covers about 77 thousand hectares of land in 2011-12 but it was 71 thousand hectares in 2012-13 (DAE, 2014). Unavailability of retting water on time, poor quality seed, pest attack and abrupt fluctuation in market price are main reasons behind decline in jute area. It this context mungbean could be introduced after harvesting of lentil in February to replace jute. Then T.Aus rice (var. BRRI dhan 48) could easily be transplanted in the $2^{\text {nd }}$ week of May after $1^{\text {st }}$ picking of Mungbean. Inclusion of pulse crop like, mungbean in the cropping pattern would maintain a good health of soil (Sharma and Prasad, 1999). T.Aman rice (var. BRRIdhan 62) could be transplanted in the $3^{\text {rd }}$ week of August and thus harvested within last week of October. Hence, Lentil-Mungbean-T.Aus rice-T.Aman rice could be developed as an alternate cropping to increase cropping intensity as well as maintain soil fertility. The study was therefore carried out to find out the performance of the alternative cropping pattern with a view to increase cropping intensity and total productivity as well as farmers' income.

\section{Materials and Methods}

The experiment was carried out in farmers' field at FSRD site, Hatgobindapur, Faridpur during two consecutive years (2014-15 and 2015-16) to develop an alternate cropping pattern to increase cropping intensity and productivity against the existing cropping Lentil-Jute-T.Aman rice. The experimental field belongs to the agro-ecological zone of Low Ganges River Floodplain Soil (AEZ\#12). The initial soil of the experimental plots was clay loam in texture with average organic matter content $1.26 \%$ and $\mathrm{pH} 7.6$ (slightly alkaline). The total nitrogen content was $0.07 \%$ (very low) and $\mathrm{K}$ content was $0.39 \mathrm{meq} / 100 \mathrm{~g}$ soil (high). 
Available $\mathrm{P}$ and $\mathrm{S}$ were $33.5 \mu \mathrm{g} / \mathrm{g}$ soil (high) and $15.2 \mu \mathrm{g} / \mathrm{g}$ soil (medium), respectively (Table 8 ). The average maximum temperature of two experimental years was $34.62^{\circ} \mathrm{C}$ (recorded in the month of April) and that of minimum was $12.48^{0} \mathrm{C}$ (recorded in the month of January); while the average maximum total rainfall was $518.30 \mathrm{~mm}$ (in July) and minimum was $2.85 \mathrm{~mm}$ (in January) during the study period. No rainfall occurred during the period of November (Appendix Table 3). The alternate cropping pattern Lentil (var. BARI Masur-7)- Mungbean (var. BARI Mung-6)- T.Aus rice (var. BRRI dhan48)- T.Aman rice (var. BRRI dhan62) was tested against the existing cropping pattern Lentil (var. Local)- Jute (var. JRO 524)- T.Aman rice (var. BRRI dhan33). The trial was conducted in five selected farmers' field, considering each farmer as a replication (dispersed). The four crops of alternate pattern were grown in lands near to lands having existing cropping pattern following the time frame. The stipulated time frame for alternate and existing cropping pattern is shown in Table 1.

Table 1. Time frame of the alternate and existing cropping pattern

\begin{tabular}{|c|c|c|c|c|}
\hline $\begin{array}{l}\text { Alternate } \\
\text { Pattern }\end{array}$ & $\begin{array}{c}\text { Lentil } \\
\text { (var. BARI } \\
\text { Masur-7) }\end{array}$ & $\begin{array}{c}\text { Mungbean } \\
\text { (var. BARI } \\
\text { Mung-6) }\end{array}$ & $\begin{array}{c}\text { T.Aus rice } \\
\text { (var. BRRI } \\
\text { dhan48) }\end{array}$ & $\begin{array}{c}\text { T.Aman rice } \\
\text { (var. BRRI } \\
\text { dhan62) }\end{array}$ \\
\hline $\begin{array}{l}\text { Total duration } \\
\text { ( } 340 \text { days) }\end{array}$ & $\begin{array}{c}30 \text { Oct to } 20 \\
\text { Feb } \\
\text { (113 days) }\end{array}$ & $\begin{array}{c}25 \text { Feb to } 30 \\
\text { Apr } \\
\text { (65 days) }\end{array}$ & $\begin{array}{l}10 \text { May to } 05 \\
\text { Aug } \\
\text { (86 days) } \\
\text { Seed sowing: } \\
16 \text { April }\end{array}$ & $\begin{array}{l}10 \text { Aug to } 25 \\
\text { Oct } \\
\text { ( } 76 \text { days) } \\
\text { Seed sowing: } \\
\text { 01 July }\end{array}$ \\
\hline $\begin{array}{l}\text { Turn around } \\
\text { time (day) }\end{array}$ & 05 & 05 & 10 & 05 \\
\hline
\end{tabular}

\begin{tabular}{lcc|c|c}
\hline Existing Pattern & $\begin{array}{c}\text { Lentil } \\
\text { (var. Local) }\end{array}$ & $\begin{array}{c}\text { Jute } \\
\text { (var. JRO 524) }\end{array}$ & $\begin{array}{c}\text { T.Aman rice } \\
\text { (var. BRRI dhan33) }\end{array}$ \\
\hline $\begin{array}{l}\text { Total duration } \\
\text { days) }\end{array}$ & $(313$ & 25 Oct to 16 Feb & 25 Mar to 20 July & 01 Aug to 20 Oct \\
(115 days) & (117 days) & (81 days) \\
$\begin{array}{l}\text { Turn around time } \\
\text { (day) }\end{array}$ & 05 & 36 & 11 \\
\hline
\end{tabular}

The crop management practices followed in the alternate cropping pattern of two years (2014-15 and 2015-16) are stated below:

Lentil: Lentil var. BARI Masur-7 was used in the cropping pattern of LentilMungbean-T. Aus rice and T.Aman rice where fertilizers were used at the rate of 24-32-22-9-2-1 kg ha ${ }^{-1}$ N-P-K-S-Zn-B in the field. All the fertilizers were applied at final land preparation. The seeds were sown on 31 October to 6 November in 2014 and 5-6 November in 2015. One hand weeding was done at 25 to 29 days after sowing (DAS) for uprooting of weeds mainly Shiyal Kata (Argemone 
Mexicana). Pre-sowing irrigation was done for bringing optimum joe condition in each year. The fungicide, Rovral @ $2 \mathrm{~g} \mathrm{lit}^{-1}$ water at 82 to 96 DAS was sprayed to control Stemphylium blight. The crop was harvested at 114 to 118 DAS (26 -28 Feb) in 2015 and 115-116 DAS (March 1-2) in 2016.

Mungbean: Mungbean var. BARI Mung- 6 was used in the alternate cropping pattern of Lentil-Mungbean-T. Aus rice and T.Aman rice where fertilizers were used at the rate of 24-32-22-9-2-0 $\mathrm{kg} \mathrm{ha}^{-1} \mathrm{~N}-\mathrm{P}-\mathrm{K}-\mathrm{S}-\mathrm{Zn}-\mathrm{B}$. All the fertilizers were applied at final land preparation. The seeds were sown on 5 to 6 March in 2015 and 6-7 March in 2016. One hand weeding at 20 to 25 DAS was done. Pre sowing irrigation was applied for bringing optimum joe condition. Only one picking of BARI Mung- 6 was done on 8-9 May 2015 (64 DAS) but 18-19 May in 2016 (71 DAS). After harvest mungbean plants were incorporated with the soil.

T.Aus rice: T. Aus rice var. BRRI dhan 48 was used in the alternate cropping pattern of Lentil-Mungbean-T. Aus rice and T.Aman rice with fertilizer dose of 80-20-20-8-1-0 kg ha-1 N-P-K-S-Zn-B. All of phosphorus, potassium, sulphur and zinc was applied as broadcast and incorporated during final land preparation. Nitrogen was applied in two equal splits as top dress at 10-15 and 30-35 DAT (days after transplanting). Twenty two days old seedlings were transplanted on 16-17 May, 2015 (21-22 days left) due to delay sowing of seeds in seedbed and 25 days old seedlings were transplanted for second cycle in 2016. One to two hand weeding were done in both the cycle. Irrigation was done 12-15 times in the month of May (148.90 mm rainfall) due to insufficient rainfall in 2015 but only three irrigations were applied in June 2015 due to higher amount of rainfall (345.3 mm). Maximum temperature $\left({ }^{\circ} \mathrm{C}\right)$, no. of rainfall days and amount of rainfall recorded during T.Aus rice cultivation (May to June 2015) under LentilMungbean-T.Aus rice-T.Aman rice are stated below in Table 2. However, weather data of October 2014 to September 2015 and October 2015 to September 2016 are presented in Appendix Table-1 and Appendix Table-2, respectively.

Table 2. Weather data during May to June 2015 for T.Aus rice cultivation

\begin{tabular}{lcc}
\hline Parameter & May 2015 & June 2015 \\
\hline Maximum temperature $\left({ }^{\circ} \mathrm{C}\right)$ & 36.8 & 36.7 \\
Total rainfall $(\mathrm{mm})$ & 148.9 & 345.3 \\
Number of Rainfall days & 14 & 19 \\
Rainfall range $(\mathrm{mm})$ & $0.2-78.4$ & $0.2-103.4$ \\
\hline
\end{tabular}

The integrated pest management (Perching, light trap) approach was given priority than using of chemical pesticide. BRRI dhan 48 was harvested on 5 to 13 August in 2015 (109 to 116 DAT) and 7-8 August for second cycle in 2016. 


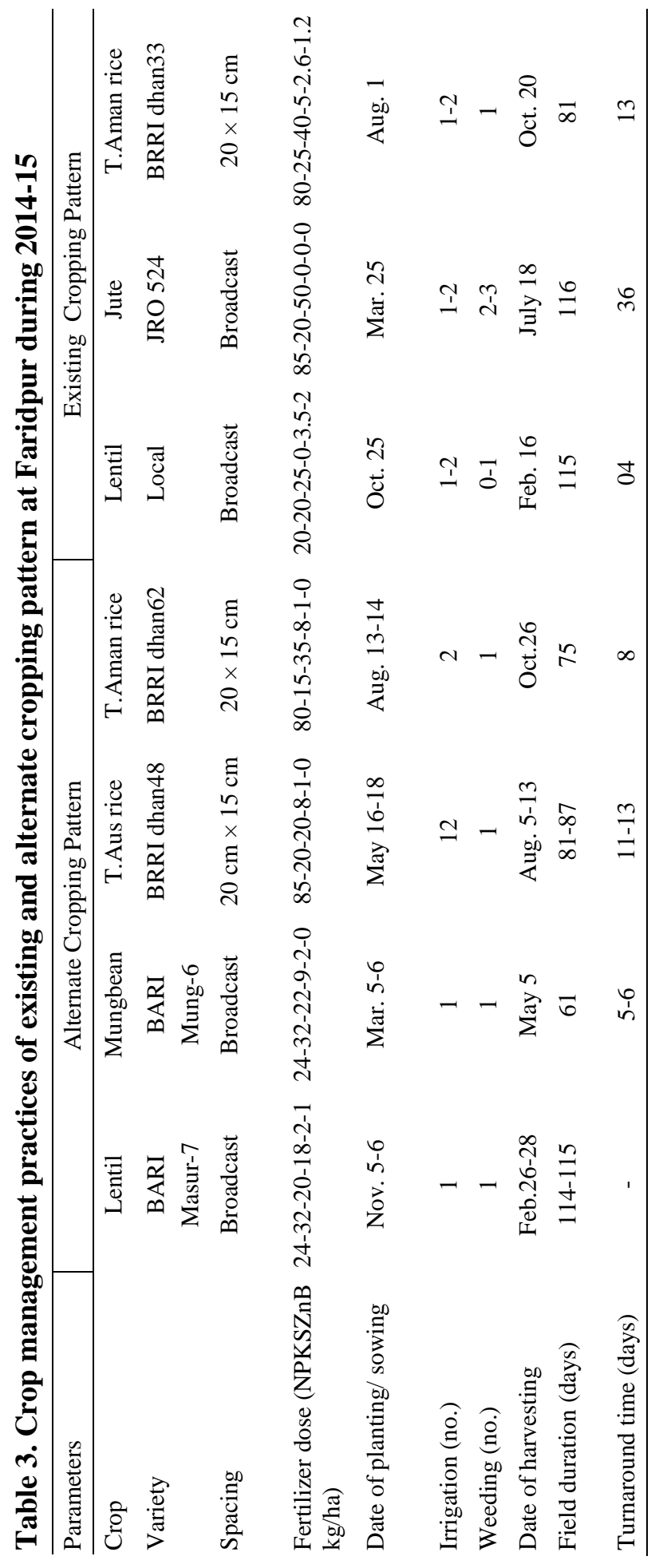


T.Aman rice: T.Aman rice var. BRRI dhan62 was used for T.Aman rice - the fourth crop of the cropping pattern Lentil-Mungbean-T. Aus rice and T.Aman rice. About 25-26 days old seedlings were transplanted in both 2015 and 2016 due to delay in harvesting of T.Aus rice. Fertilizers were used at the rate of 8015-35-8-1-0 $\mathrm{kg} \mathrm{ha}^{-1} \mathrm{~N}-\mathrm{P}-\mathrm{K}-\mathrm{S}-\mathrm{Zn}-\mathrm{B}$ in the field. All of phosphorus, potassium, sulphur and zinc was applied as broadcast and incorporated during final land preparation. Nitrogen was applied in three equal splits. The first one-third was applied immediately after seedling establishment stage (7-10 DAT), second top dress at rapid tillering stage (28-30 DAT) and third one was applied at panicle initiation stage (43-46 DAT). One weeding was done by spraying weedicide (Changer) at 7-8 DAT. Irrigation was done twice in both the years. The integrated pest management (Perching, light trap, etc.) approach was used along with insecticide (Regent, Virtako, etc.) to control the pest. BRRI dhan62 was harvested on 26-27 October, 2015, (100 to 101 seed to seed) for both years irrespective of farmers.

Thus total field duration of the alternate pattern was 331 and 340 days in 2015 and 2016, respectively. On the other hand, field duration of whole existing pattern was 312 and 318 days in 2015 and 2016, respectively. The crop management practices of two years (2014-15 to 2015-16) of the existing cropping pattern and alternate cropping pattern are presented in Table 3 and Table 4. Data regarding existing cropping pattern (Lentil-Jute-T.Aman rice) were recorded from fields adjacent to the experimental plots.

Data on yield parameters and yield of each of the crops were collected following standard procedures. Agronomic performance like, field duration, production efficiency and rice equivalent yield of cropping patterns were calculated. Production efficiency value in terms of $\mathrm{kg} / \mathrm{ha} / \mathrm{day}$ was calculated by total main product in a cropping pattern divided by total duration of crops in that pattern (Tomar and Tiwari, 1990).

Production Efficiency $(\mathrm{kg} / \mathrm{ha} /$ day $)=\frac{\sum \mathrm{Y}_{\mathrm{i}}}{\sum \mathrm{d}_{\mathrm{i}}}$

Where, $\mathrm{Y}_{\mathrm{i}}=$ Yield $(\mathrm{kg})$ of $\mathrm{i}^{\text {th }}$ crop and $\mathrm{d}_{\mathrm{i}}=$ Duration (day) of $\mathrm{i}^{\text {th }}$ crop of the pattern

$$
\mathrm{i}=1,2,3,4
$$

Rice Equivalent Yield (REY): For comparison between crop sequences, the yield of every crop was converted into rice equivalent on the basis of prevailing market price of individual crop (Verma and Modgal, 1983). Rice equivalent yield (REY) was computed as yield of individual crop multiplied by market price of that crop divided by market price of rice.

Rice equivalent yield $(\mathrm{t} / \mathrm{ha} / \mathrm{yr})=\frac{\text { Yield of individual crop } \times \text { marketprice of thatcrop }}{\text { Marketprice of rice }}$ 
For the economic analysis, gross return, gross margin and marginal benefit cost ratio was calculated on the basis of prevailing market price of the produces. Economic analysis involved collection of data on prices and quantities of inputs used and output produced. The inputs used included seed, fertilizer, labour, herbicide and insecticides. The MBCR of the existing cropping pattern and any replacement for it can be computed as the marginal value product ((MVP) over the marginal value cost (MVC). The Marginal of prevalent pattern (F) and any potential replacement (E) for it was computed as (CIMMYT, 1988).

$$
\text { Marginal Benefit Cost Ratio }(\text { MBCR })=\frac{\text { Gross return }(E)-\text { Gross return }(F)}{\operatorname{TVC}(E)-T V C(F)}=\frac{M V P}{M V C}
$$

Where, $\mathrm{TVC}=$ Total variable cost $\mathrm{MVP}=$ Marginal value of product MVC $=$ Marginal value cost

The nutrient uptake by different crops in both alternate and existing pattern was calculated according to Fertilizer Recommendation Guide (FRG, 2012).

\section{Results and Discussion}

Yield performance: Year-wise (2014-15 and 2015-16) information regarding yield and cropping duration in the alternate cropping pattern (AP) and existing pattern (EP) are presented in Table $5 \&$ Table 6 . All of parameters showed the highest value in AP compared to that of EP. During 2014-15, the rice equivalent yield $(17.90 \mathrm{t} / \mathrm{ha} / \mathrm{yr})$ and production efficiency $(29.79 \mathrm{~kg} / \mathrm{ha} /$ day $)$ was higher in AP than EP (Table 5). Similar results were also found in 2015-16, alternate cropping pattern provided higher rice equivalent yield $(16.47 \mathrm{t} / \mathrm{ha} / \mathrm{yr})$ and production efficiency $(28.42 \mathrm{~kg} / \mathrm{ha} /$ day) than existing cropping pattern (Table 6). Average yield of lentil, mungbean, T.Aus rice and T.Aman rice in the AP were $1.31,0.80,3.75$ and $4.17 \mathrm{t} / \mathrm{ha}$; while the yield of lentil, jute and T.Aman rice in the EP were 1.00, 2.48 and $3.40 \mathrm{t} / \mathrm{ha}$, respectively (Table 7). On an average, AP gave higher rice equivalent yield (REY) of $17.19 \mathrm{t} / \mathrm{ha} / \mathrm{yr}$ against EP (14.59 $\mathrm{t} / \mathrm{ha} / \mathrm{yr}$ ). Higher rice equivalent yield was obtained from AP due to introduction of two new crops mungbean and T.Aus rice instead of jute. Thus REY obtained from the AP was $18 \%$ higher than that of EP. The EP (Lentil-Jute-T.Aman rice) required on an average 313 days field duration to complete the cycle while AP (Lentil-Mungbean-T.Aus rice-T.Aman rice) required 340 days (excluding seedling age of rice) to complete one cycle. The AP showed 35\% production efficiency over EP (average production efficiency of alternate and existing pattern was 28.90 and $21.50 \mathrm{~kg} / \mathrm{ha} /$ day, respectively, as shown in Table-7). Results indicated that mungbean (BARI Mung-6) and lentil (BARI Masur-7) could easily be fitted in the existing cropping pattern keeping 25 days turnaround time in a year. 


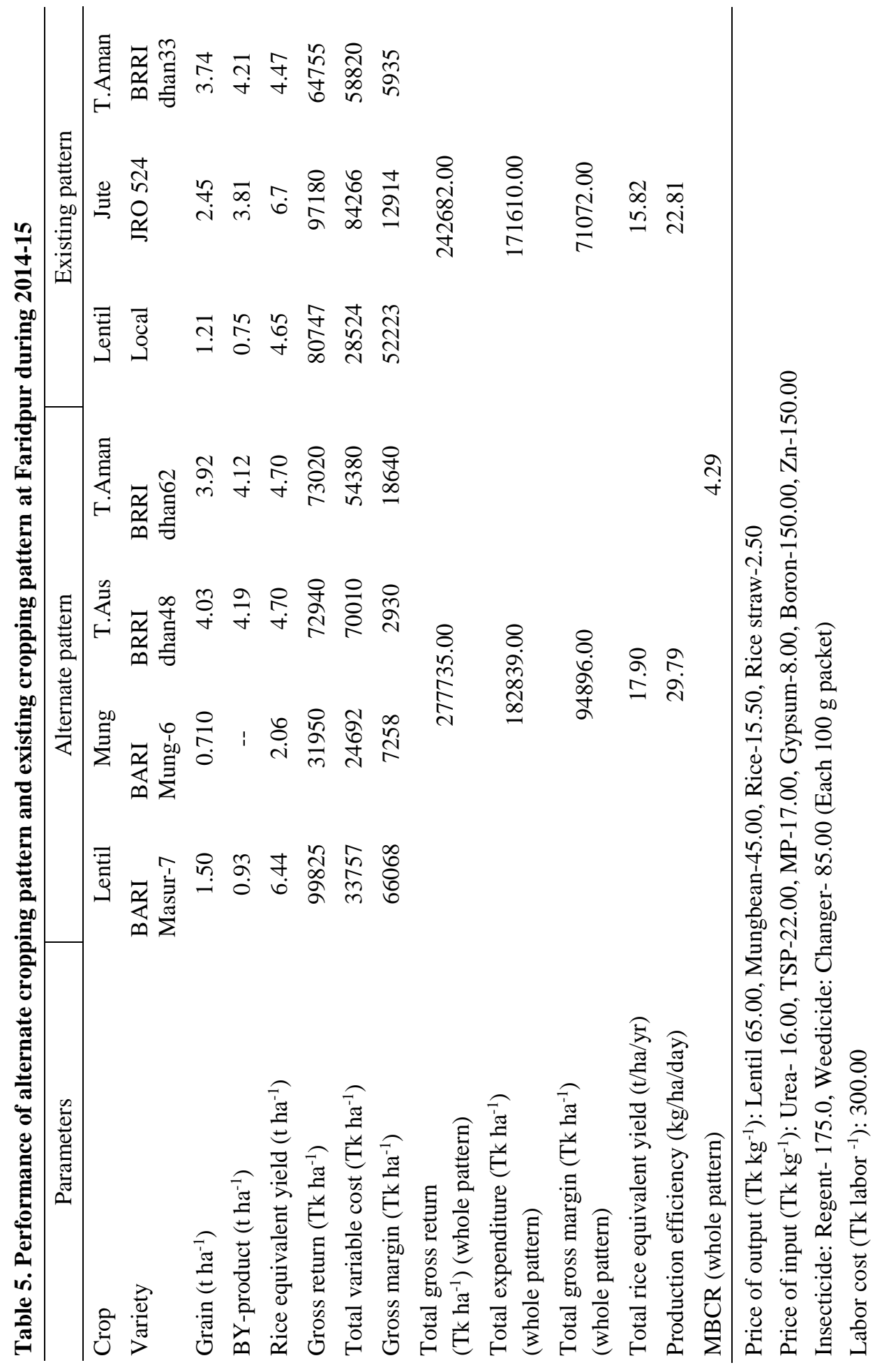




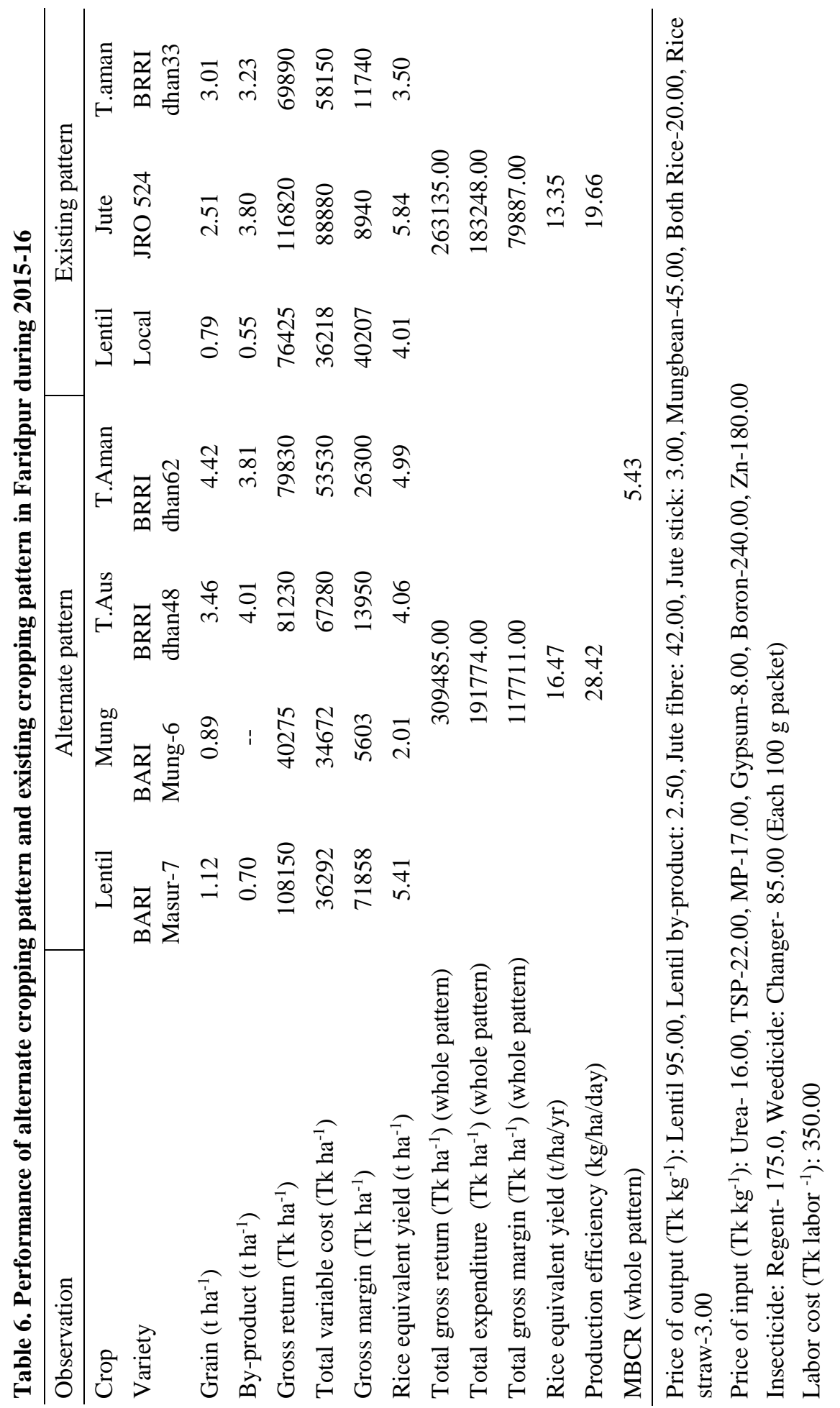




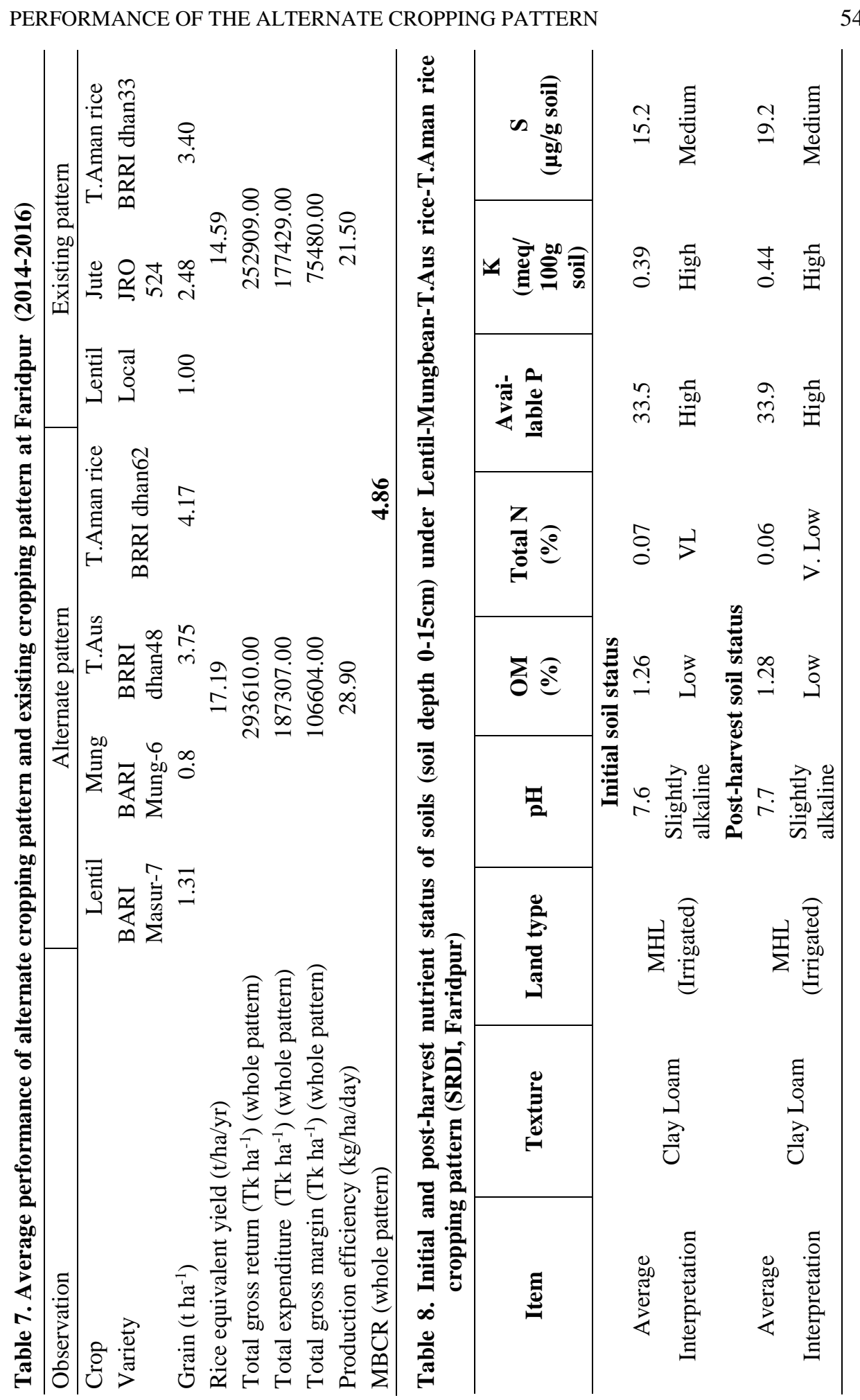




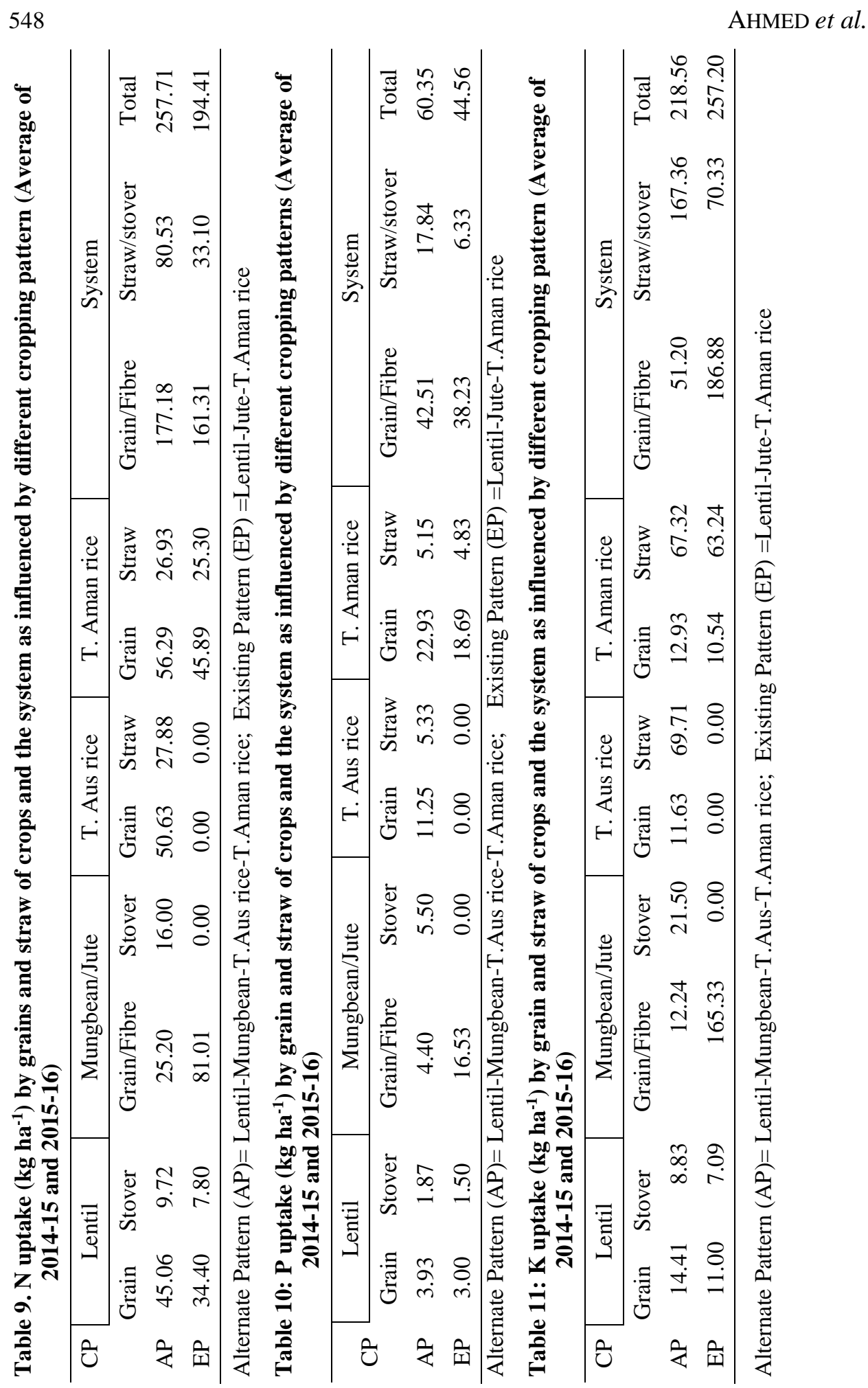


Cost and return: The details of economic analysis of two years (2014-15 to 2015-16) are presented in Table 5 and Table 6 . Economics of system productivity of the two cropping patterns showed that the gross return and gross margin varied between the cropping patterns. From average of two years, higher gross return (Tk. 293610/ha) and gross margin (Tk.106304/ha) were obtained from AP (Lentil-Mungbean-T.Aus rice-T.Aman rice) and lower gross return (Tk. 252909/ha) and gross margin (Tk. 75480/ha) was found in EP (Lentil-JuteT.Aman rice). Thus, the AP provided $42 \%$ higher gross margin than EP due to harvesting additional yields from two crops mungbean and T.Aus rice instead of growing jute only. Higher (Tk.187307/ha) total variable cost was recorded from AP due to inclusion of T.Aus rice and mungbean which was $5.57 \%$ higher than the total variable cost in EP (Tk.177429/ha). The average MBCR was 4.86 which indicating that alternate pattern could produce more economic returns over the farmers' existing pattern (Table 7).

Soil analysis: Initial and post-harvest soil sample analytical data were shown in Table 8. The sol analysis showed that, except $\mathrm{N}$ all other nutrient contents increased slightly which might be due to inclusion of two pulse crops (lentil and mungbean) in the alternate cropping pattern (AP). There was also possibility of increasing $\mathrm{N}$ content in the soil as two legume crops were grown in the alternate pattern, but it did not happen which might be due to leaching, runoff and volatilization loss of $\mathrm{N}$ through cultivation of subsequent $\mathrm{T}$.Aus rice and T.Aman rice shortly after harvest of mungbean and keeping standing water in both T.Aus and field.

\section{Apparent nutrient uptake and balance}

$\mathrm{N}$ uptake in grain was $177.18 \mathrm{~kg} \mathrm{ha}^{-1}$ for whole AP whereas $161.31 \mathrm{~kg} \mathrm{ha}^{-1}$ for EP (Table 9). The higher $\mathrm{N}$ uptake in grain $\left(56.29 \mathrm{~kg} \mathrm{ha}^{-1}\right)$ was found from T.Aman rice and lower from mungbean $\left(25.20 \mathrm{~kg} \mathrm{ha}^{-1}\right)$ in AP (Table 9). In EP, due to lower yield of T.Aman rice, $\mathrm{N}$ uptake was $23 \%$ lower than that of AP. The total $\mathrm{N}$ uptake was $257.71 \mathrm{~kg} \mathrm{ha}^{-1}$ and $194.41 \mathrm{~kg} \mathrm{ha}^{-1}$ in AP and EP, respectively. In both the system, negative $\mathrm{N}$ balance was found. But, deficit was higher in EP than AP might be due to use of lower fertilizer dose $\left(185 \mathrm{~kg} \mathrm{ha}^{-1}\right)$ and addition of no residues to soil (Fig. 1). In case of P uptake, total uptake in AP and EP was $60.35 \mathrm{~kg} \mathrm{ha}^{-1}$ and $44.56 \mathrm{~kg} \mathrm{ha}^{-1}$, respectively (Table 10). Nutrient balance was in surplus for both the system (Fig. 1). In case of $\mathrm{K}$ uptake, the highest amount of $\mathrm{K}$ uptake (165.33 $\left.\mathrm{kg} \mathrm{ha}^{-1}\right)$ was found in jute in EP which was higher than all the crops in both the systems. Total K uptake was 18\% higher in EP compared to AP might be due to higher fertilizer dose (Table 11). The balance was consistently negative being higher $\left(-142.20 \mathrm{~kg} \mathrm{ha}^{-1}\right)$ in EP and lower $\left(-81.00 \mathrm{~kg} \mathrm{ha}^{-1}\right)$ in AP (Fig. 1). 
N-uptake

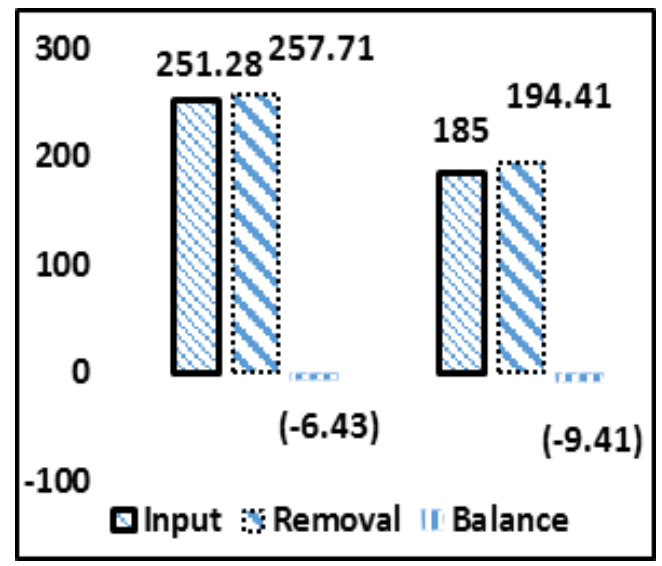

P-uptake

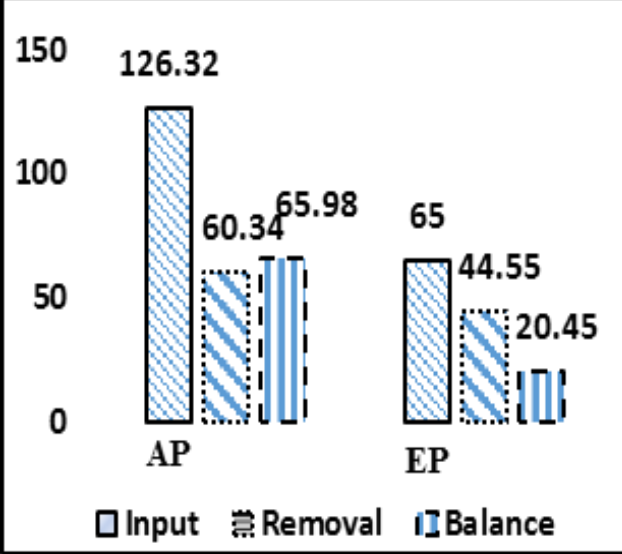

K-uptake

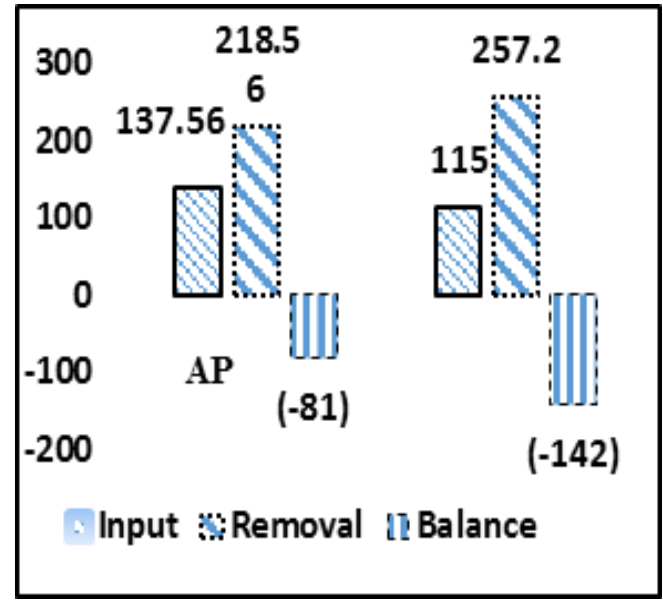

Fig 1. Inputs, outputs and balance of $N, P$ and $K\left(\mathrm{~kg} \mathrm{ha}^{-1}\right)$ in response to alternate and existing cropping patterns in 2014-15 and 2015-16.

\section{Conclusion}

From the results, alternate cropping pattern (Lentil-Mungbean-T.Aus riceT.Aman rice) was found agronomically viable in terms of REY and production efficiency. Besides, MBCR from the alternate cropping pattern showed the pattern economically viable. On an average, 340 days required to complete the one cycle of the alternate cropping pattern with turn around time of 25 days only. So, more efforts should be given in labour management, timely supply of inputs and land preparation. In this alternate cropping pattern, two pulse crops (Mungbean and lentil) could be fitted in the rice based pattern to increase the pulse production as well as enhance soil fertility. 


\section{References}

Aziz, M.A., M.A. Baker, A. Hamid, M.J. Uddin and M.M. Haque. 2008. Bangladeshe Mung Daler Chash, Strengthening of pulses and oilseed research programme in Bangladesh, BARI, Gazipur.

Aziz, M.A. and M.M. Rahman. 2011. Bangladeshe Mungdaler Chash, Strengthening of Pulses \& Oilseed research programme in Bangladesh, BARI, Gazipur.

BBS (Bangladesh Bureau of Statistics). 2016. Year book of Agricultural Statistics-2015 $27^{\text {th }}$ series. Statistics and Informatics Division (SID), Ministry of Planning, Government of the People's Republic of Bangladesh. pp 3.

BBS (Bangladesh Bureau of Statistics). 2017. Statistical year book of Bangladesh. Bangladesh Bureau of Statistics. Ministry of Planning, Dhaka, Bangladesh.

CIMMYT. 1988. From Agronomic Data to Farmer Recommendations: An Economic Training Manual. Completely revised edition. Mexico. D.F.

DAE (Department of Agriculture Extension). 2014. Annual Report 2013-14. Report presented in the Regional Research and Extension Program Review and Planning Workshop 2014 held during 27-29 May 2014 at RARS, BARI, Rahmatpur, Barisal.

FRG. 2012. Fertilizer Recommendation Guide, 2012. Bangladesh Agricultural Research Council (BARC), Farmgate, Dhaka 1215. pp 07.

Sharma, S.N. and Prasad, R. 1999. Effect of Sesbania green manuring and mungbean residue incorporation on productivity and nitrogen uptake of a rice-wheat cropping system. bioresource Technology 67 (2): 171-175.

Tomer, S.S. and Tiwari, A.S. 1990. Production potential and economics of different crop sequences. Indian J. Agron. 35 (1\&2): 30-35.

Verma, S. P. and Modgal, S. C. 1983. Production potential and economics of fertilizer application as resources constraints in maize, wheat crop sequence. Himachal $J$. of Agric. Res., 9 (2), 89-92. 


\begin{tabular}{l|c|c|c|c}
\multicolumn{5}{l}{ Appendix Table 1. Weather data at Faridpur from October 2014 to September 2015 } \\
\hline Month & Avr. Max $\left({ }^{\circ} \mathrm{C}\right)$ & Avr. Min $\left({ }^{\circ} \mathrm{C}\right)$ & Avr. $\mathrm{RH}(\%)$ & Total rainfall $(\mathrm{mm})$ \\
\hline October 2014 & 32.56 & 23.58 & 81.03 & 83.2 \\
November & 30.42 & 18.08 & 78.13 & 000.0 \\
2014 & & & & \\
December & 24.72 & 13.90 & 85.19 & 000.0 \\
2014 & & & & \\
January 2015 & 24.59 & 13.10 & 81.93 & 5.7 \\
February & 28.50 & 15.43 & 76.75 & 21.2 \\
2015 & & & & \\
March 2015 & 32.75 & 18.73 & 65.32 & 2.8 \\
April 2015 & 33.12 & 22.83 & 76.27 & 160 \\
May 2015 & 36.8 & 21.4 & 79 & 148.9 \\
June 2015 & 36.7 & 23.0 & 84.86 & 345.3 \\
July 2015 & 32.07 & 26.03 & 87.77 & 539.3 \\
August 2015 & 32.68 & 26.73 & 86.90 & 312.2 \\
September & 33.46 & 26.22 & 85.9 & 213.37 \\
2015 & & & & \\
\hline
\end{tabular}

Appendix Table 2. Average weather data at Faridpur from October 2015 to September 2016

\begin{tabular}{lccccc}
\hline Month & Avr. Max $\left({ }^{\circ} \mathrm{C}\right)$ & Avr. Min $\left({ }^{\circ} \mathrm{C}\right)$ & Avr. RH $(\%)$ & Total rainfall $(\mathrm{mm})$ \\
\hline October 2015 & 32.92 & 23.89 & 81 & 79.4 \\
November 2015 & 30.62 & 19.06 & 80.03 & 000.0 \\
December 2015 & 25.93 & 15.15 & 81.51 & 006.0 \\
January 2016 & 25.16 & 11.86 & 80.51 & 000.0 \\
February 2016 & 30.06 & 17.78 & 75.24 & 15.8 \\
March 2016 & 34.07 & 21.05 & 68.68 & 024.4 \\
April 2016 & 36.11 & 26.23 & 74.50 & 57.2 \\
May 2016 & 33.22 & 24.71 & 79.80 & 222 \\
June 2016 & 34.08 & 26.22 & 82.73 & 282.2 \\
July 2016 & 32.28 & 26.35 & 88.13 & 497.3 \\
August 2016 & 33.13 & 26.67 & 83.84 & 303.10 \\
September 2016 & 33.31 & 26.36 & 86.03 & 124.7 \\
\hline
\end{tabular}

